\title{
MUSEET OG KUNSTENS ISCENESÆTTELSE
}

\author{
Vibeke Petersen
}

I 1990'erne er iscenesattelse blevet et begreb på linie med de andre kunstkategorier. Med det iscenesatte fotografis gennembrud i 1980'erne og installationskunstens tilsynekomst $i$ 1990'erne har vi allerede fäet en introduktion til en iscenesat kunst. Men at iscenesatte "noget» er i sig selv blevet til en disciplin, der inden for billedkunstens område har fået langt videre perspektiver. Kunstneren må pludselig finde sig $i$ at vere én blandt flere parter $i$ dette anliggende. Der foregarr $i$ dag et langt mere intenst samspil mellem samtidens kunstneriske udtryksformer og de institutionelle rammer. Hvad betyder det for kunstmuseet og kunsten og kunstneren?

Kunstens iscenesættelse har til alle tider været foranderlig. Alt efter hvilket formål og behov der lå bag kunstens placering $\mathrm{i}$ tid og sted.

I Antikken var det tilbedelsen af guderne der styrede kunstskattenes placering: Omkring gudestatuen.

I Middelalderen blev Kristendommens budskab lanceret gennem billeder, således at budskabet kunne belære den almindelige befolkning. Det at iscenesxtte noget er tæt forbundet med et ønske om at formidle noget på en helt bestemt måde. Dette "noget» kan rumme alle aspekter af magt det være sig af religiøst eller politisk art.

Der er således intet nyt under solen.

Kunsten er blevet brugt til det hele.

Men når vi i dag taler om iscenesættelse er det forstået som et selvstændigt udtryk på linie med de andre kunstkatagorier.

Museumsfolkene inviterer kunstnerne til at iscenesætte museets permanente samlinger. Dette kan både dreje sig om den ældre kunst og den moderne kunst. Kunstnerne har hermed faet et andet ærinde end blot at producere værker, som museet kan være interesseret $\mathrm{i}$ at erhverve. Der er etableret et samarbejdsforhold, hvor kunstneren «låner» sin autoritet til institutionen. Dette skal ses i erkendelse af at kunstneren med sit udogmatiske syn kan tilføre museets samlinger andre måder at præsentere dem på.

Men det holder ikke op dér. Kunsthistorikerne er også selv med til at tage têten i præsentationen af kunstværkerne. Men flere og flere uden for dette snævre miljø arrangerer også udstillinger. Arten af udstillinger kan spænde vidt fra traditionelle «museums»udstillinger til eksperimenterende og meget omfattende udstillinger. Udstillingsvirksomhed er i sig selv 
116 blevet en disciplin. Antallet af udstillingssteder er blevet kraftigt forøget. Som aldrig før er der siden 1980'erne blevet både bygget og oprettet udstillingssteder.

Dette er tæt forbundet med den omfattende udstillingsaktivitet, der har været dominerende siden 1960'erne overalt i den vestlige verden. Hvor kunstmuseer, gallerier og andre udstillingssteder har konkurreret voldsomt om kunstnerens gunst og dennes værk. Kunstmuseernes succes er blevet målt i hvor mange udstillinger de har kunnet vise på et år.

Men før dette ræs for alvor satte ind skal vi egentlig længere tilbage $\mathrm{i}$ tid, nemlig til anden halvdel af 1800-tallet. Det er i dette tidsrum, at kunstmuseet som institution for alvor bliver etableret over for den brede offentlighed.

\section{KUNSTMUSEET - SAMLINGERNE OG HISTORIEN}

I 1800-tallet og for den sags skyld langt op $\mathrm{i}$ vort eget århundrede har det primært været disse to områder, der var fundamentet i museets virke.

Kunstmuseerne blev i 1800-tallet opført som «templer», der i nogle få timer om dagen eller sågar om ugen var tilgængelige for publikum, det dannede borgerskab. De forstod rigdommen i maleri- og skulptursamlingerne. Værkerne var placeret tæt ved siden af hinanden og over hinanden. Det var store og små værker i en skøn forening. Samlingerne skulle præsenteres så hele som overhovedet muligt. Med tiden var det nødvendigt at skabe en systematik og kronologi, der gav publikum et overblik over værkernes status. Dette medførte at værkerne blev ophængt efter perioder, skoler eller stilretninger.
Kunstmuseet har i det 20. århundrede fået ændret sin position.

Samlingerne er for manges vedkommende over hele verden blevet adskilt i ældre kunst og moderne kunst. Dette har medført, at der overalt er blevet opført nye bygninger til den moderne kunst.

I det moderne museums permanente samlinger er ophængningen stærkt præget af en æstetik, der tillader det enkelte værk, at få sit selvstændige "rum» på væggen. Dog har kunstmuseerne stadig det til fælles uanset om de huser den ældre kunst eller den moderne kunst, at de indsamler, registrerer, opbevarer, forsker og formidler de kunstværker, der er kommet inden for $\mathrm{i}$ museerne.

\section{KUNSTMUSEET OG UDSTILLINGERNE}

Inden for museerne er udstillingsvirksomheden med tiden blevet en selvstændig disciplin. Den synliggør en praksis, hvor kernen er ønsket om at skabe en platform for andre måder at præsentere kunsten på. Behovet for en udstillingsaktivitet inden for museet hænger også sammen med at publikum har ændret sig gennem tiderne. Det er blevet mere opdelt i grupper. Der er etableret et langt tættere forhold mellem den brede offentlighed og kunsten.

Men udstillingsaktiviteten fik oprindelig sin begyndelse $\mathrm{i}$ anden halvdel af 1800 tallet med kunstnerens frihed til at producere værker. Kunstneren stod nu i det dilemma, at han/hun uopfordret kunne frembringe værker, som var fuldstændig løsrevet fra en direkte efterspørgsel. Kunstnernes position blev således paradoksalt nok mere udsat, da der blev flere muligheder for at præsentere deres værker. 
Det var på udstillingerne, at kunstnerne fik mulighed for at præsentere sig selv og deres værker. Dette frisatte kræfter, som blev banebrydende for ændrede æstetiske kriterier inden for kunst og andre beslægtede områder. For i det øjeblik, at kunstneren begyndte sit selvstændige liv, løsrevet fra samfundets store ideologiske opgaver (Kongen, adelen, kirken og staten) var der ikke længere en overordnet kontrolinstans, der kunne styre de frie "kræfter".

Kunstnerne tog initiativer til at præsentere deres kunst $\mathrm{i}$ andre sammenhænge end kunstmuseets.

Kunstnersammmenslutninger blev etableret. Hele "Gesamtkunst» idéen spredte sig som ringe i vandet omkring år 1900 . Et af de flotteste resultater blev Palais Stoclet i Bruxelles, hvor rigmanden Adolphe Stoclet hos Wiener Werkstätte i Wien i perioden 1905 -11 fik udført en totaludsmykning af sin bolig. Det var alt fra maleri, skulptur til møbler af kunstnere som Gustav Klimt, Oskar Kokoschka, Egon Schiele og Koloman Moser og med Josef Hoffmann som arkitekt. Palais Stoclet blev således til et samlende "Gesamtkunstwerk».

\section{SAMTIDENS KUNST}

Op igennem det 20. århundrede er museets forpligtigelse udover den rent kunsthistoriske også blevet at få skabt en sammenhæng og forståelse for samtidens kunst.

Museets udstillingsaktiviteter er med tiden blevet et stort område. Det er her i gennem at museet far mulighed for at påpege sammenhænge mellem praksis og teori over for publikum.

Udstillingerne fungerer i dag som præsentationer af museets arbejdsområde. På de store kunstmuseer er synliggørelsen af store konserveringsopgaver blevet en anden måde, at præsentere værkerne på. Publikum inviteres til at se kunstneren over skulderen - at få synliggjort værkets tilblivelsesproces. Behovet for også at skabe udstillinger, der belyser den klassiske kunst i et nutidigt perspektiv er af fundamental betydning for institutionen og publikum.

Det er i samspillet med samtidens kunst, at museerne har en meget synlig rolle at spille. Foranderligheden der jo i sig selv er en præmis som ligger implicit i samtidskunsten, da man jo her spiller med ukendt makker, er den dynamiske motor for udviklingen af andre måder at forholde sig til kunsten på. Og det er her at iscenesættelsen for alvor også kommer ind i dag, når museerne indkalder udstillingsarrangører uden for institutionen til at komme med nogle væsentlige kommentarer til samtidskunsten.

Vores behov for at kunne få perspektiveret nogle sammenhænge mellem historien og vores egen tid vil altid være tilstede.

\section{UDSTILLINGEN «STRANGE HOTEL»}

I 1993 blev udstillingen "Strange hotel» skabt på Århus Kunstmuseum. Vi var to museumsinspektører Ane Hejlskov Larsen og undertegnede, der efter idé af museumsdirektør Jens Erik Sørensen organiserede denne udstilling. Ideen og konceptet for udstillingen var at skabe en hotelinstallation $\mathrm{i}$ en kunstinstitution. Det var ønsket om at skabe en fortælling gennem udvalgte værker, der netop i deres indhold eller motiv refererede til menneskers ensomhed og isolation. $\mathrm{Og}$ som sådan var med til at understrege kunstens nomadiske positioner. Både indholdsmæssigt og formelt. 
118 Værkerne, der skulle indgå i udstillingen, måtte således indordnes den overordnede idé. Iscenesættelsen af værkerne var derfor dobbelt. For det første var valget af kunstværker styret af, at de skulle indgå i en ikke kunstnerisk sammenhæng. De blev tildelt en rolle, hvor de skulle agere interiør. Dog var værkerne nøje udvalgt efter hvilken betydning de gav rummet. Uden værkerne ingen betydning. Men selve opbygningen af rammen blev ligeledes styret af den overordnede idé. Nemlig at opbygningen af udstillingen skulle drejes henimod en arkitektonisk ramme, der helt bogstaveligt opfyldte fortællingens ramme - hotellet.

Værkerne skulle således leve op til flere krav på samme tid. De skulle ikke blot i deres fremtoning og udtryk kunne afgive følelsen af afmagt, desperation, forladthed, ensomhed, isolation, men også selv kunne levere en scenografi, der på en meget præcis måde entydigt fortalte beskueren hvor og i hvilken situation man befandt sig.

\section{UDSTILLINGEN BEGYNDTE I MUSEETS FORHAL}

Museets forhal blev indgangen til "hotellet» med Jeff Walls store iscenesatte fotografi "No. 1983" af en kvinde og en mand. Han passerer hende på gaden uden for et hotel. Derudover var der også lagt en rød løber ud, som var med til at understrege iscenesættelsen. Udstillingen fortsatte derfra gennem to udstillingssale, som fremtrådte med alle de karakteristika et hotel rummer. Salenes ombygning til små rum med snævre gangpartier indgav virkelig illusionen af noget klaustrofobisk og labyrintisk, og var som sådan med til at skærpe en sansning, der blot blev endnu voldsommere understreget af værkernes iscenesættelse i de forskellige rum.

At udstillingskonceptet fra starten blev accepteret af de museer, der skulle udlåne værker til udstillingen var interessant. Flere udenlandske museer udtrykte endog begejstring for ideen og var stærkt interesseret $\mathrm{i}$ at få besøgt udstillingen, når den åbnede. Udstillingen rører ved noget væsentligt i forhold til kunstværkets rolle, som deltagende objekt $\mathrm{i}$ et scenografisk landskab, der pludselig har forskudt sig over i teatrets regi. Sammensmeltningen af værkernes egen identitet og dermed autoritet og en fortællings rammeidentitet, hvori nogle kunstværker pludselig skal agere som kulisse for en overordnet idé kan dog nok opfattes som en betænkelig affære set i det retrospektive spejl. Ihvertfald satte udstillingen spørgsmåltegn ved hvem der iscenesætter hvem?

Kunstværket er i "Strange hotel» blevet til en aktiv medspiller, hvor kunstneren snarere er placeret ude på sidelinien. Medmindre kunstneren som i tilfældet med den belgiske kunstner Guillaume Bijl netop gennem sin konstruktion af "Tourist Agency» indførte dette fremmedlegeme i kunstinstitutionen. Hans «rejsebureau» fik dermed overført en kunstidentitet ved at indgå i udstillingen. Hans installation agerer ikke som kulisse til den overordnede udstillingsidé, men opfylder snarere selve ønsket om iscenesættelse. Varket er iscenesattelsen. Det samme gælder Jes Brinchs bidrag «Diskotek» til udstillingen. Det er en iscenesættelse af et rum, der allerede fra starten af har installationskarakteren, og som sådan er fleksibel til det givne formål. Der var også andre værker på udstillingen, som havde 

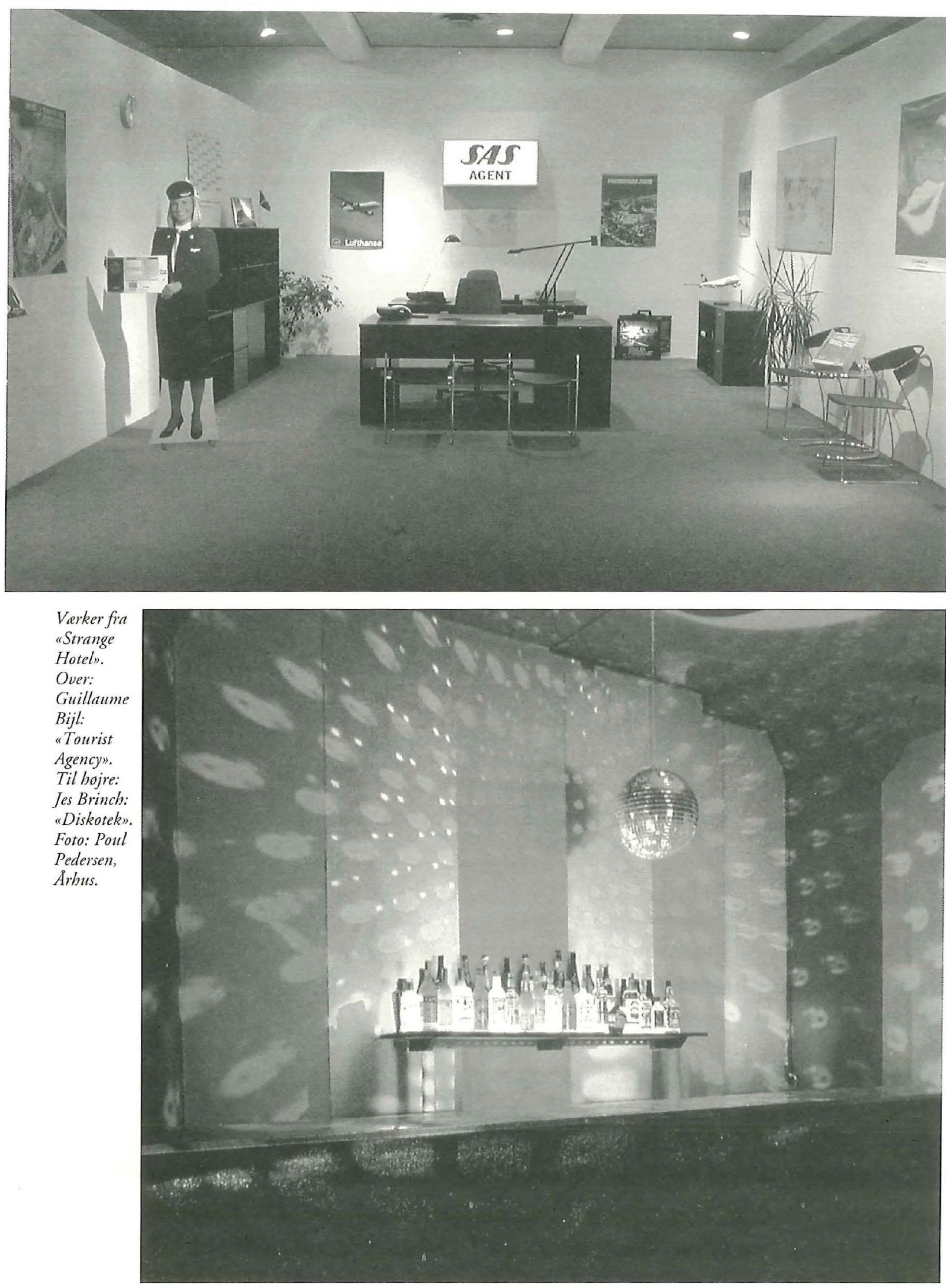

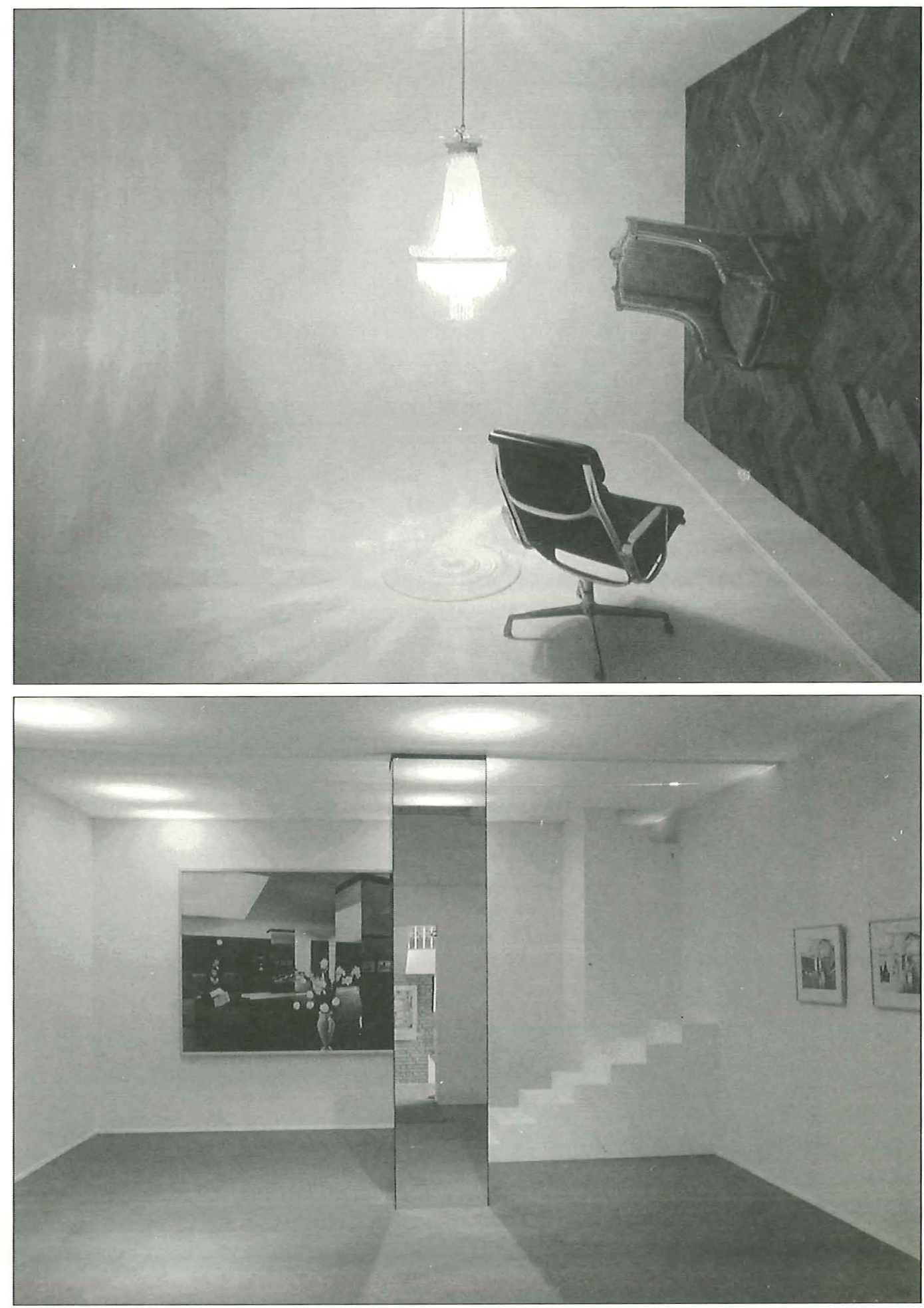

Varker fra "Strange Hotel». Over: Stephan Huber: "Ich liebe Dich».

Under: Ricard Hamilton: "Lobby». Pa motstående side: Duane Hanson: "Child with Puzzle».

Foto: Poul Pedersen, Arhus. 


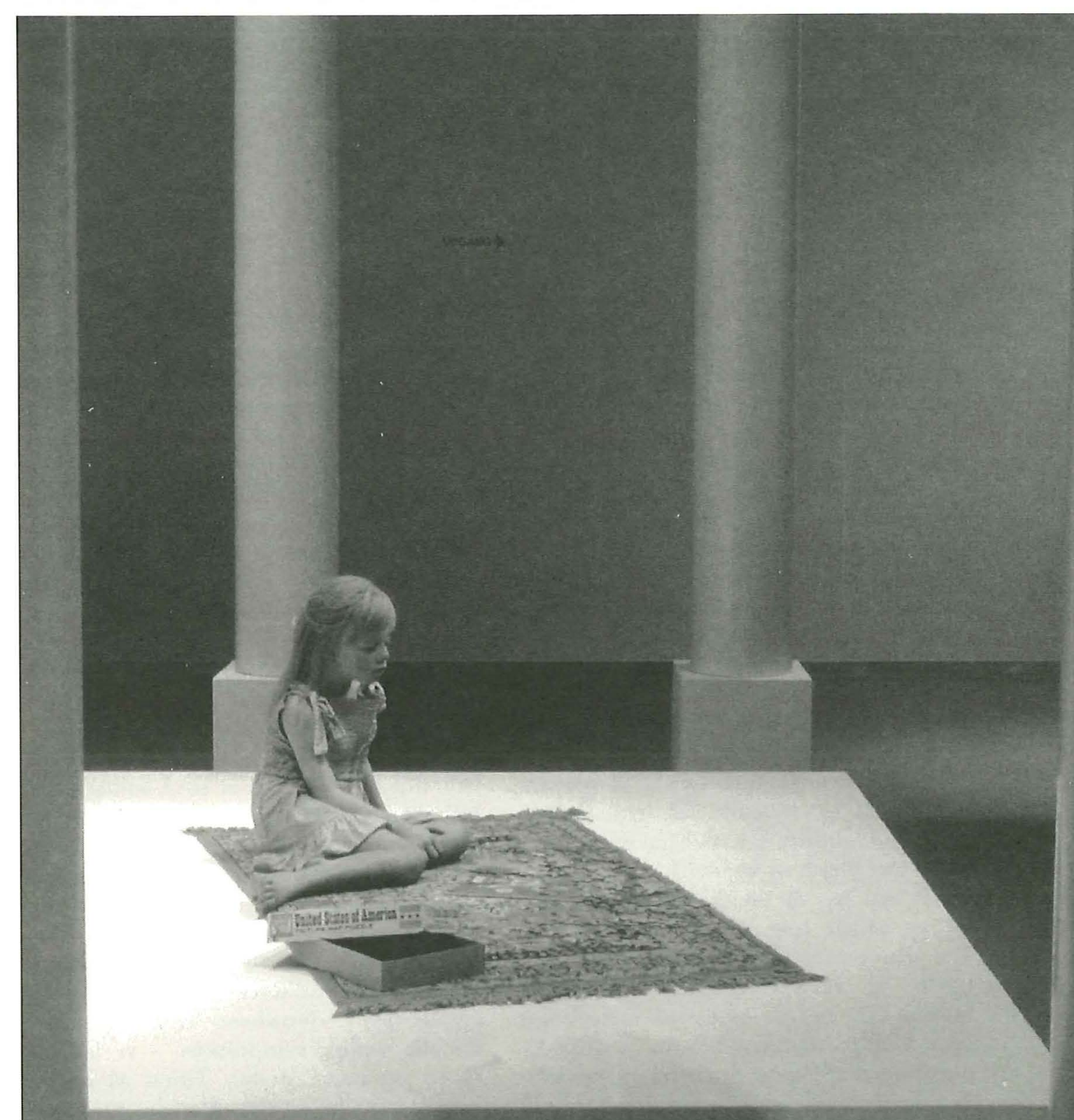


122 denne karakter. Der var Stephan Hubers rum med «Ich liebe Dich» og der var Richard Hamiltons rum "Lobby», og til nød Duane Hansons rengøringskvinde "Queenie II» og den lille pige på gulvtæppet «Child with Puzzle». Det er værker, som er skabt netop udfra denne præmis eller som $\mathrm{i}$ hvert fald kan indgå $\mathrm{i}$ denne form for iscenesættelse uden selv at få overført en identitet, de ikke ville være i stand til at klare, i modsætning til mange af de andre værker på udstillingen, som jo allerede i sig selv rummer en værkidentitet, der intet har at gøre med netop denne udstillings iscenesættelse.

Udstillingen "Strange hotel» er præsentationen af en samlende idé, hvor værkerne er underordnet denne. Men er ideen og konceptet blevet opfyldt? På en måde ja.

Selv om jeg var medpart i udstillingen vil jeg tillade mig at svare bekræftende. Det ejendommelige skete. Ud af den samlende og sammenhængende fortælling opstod i de enkelte rum små fortællinger og lokale sammenhænge. Sammenblandingen af mange forskellige typer værker skabte nogle sære betydninger i kraft af den sociale ramme de var presset ind i.

Men det var udstillingsarrangørens udstilling med kunstneren og værket som iscenesatte aktører. Publikum blev inviteret indenfor, men "indlogerede" ikke sig selv på hotellet.

\section{UDSTILLINGEN «NOWHERE» PA LOUISIANA}

Anderledes var det med udstillingen «Nowhere» på Louisiana i 1996, som viste andre veje.

Værkernes status var ikke, at de er kunst, men at de er samtids billeder på vores almene vilkår. Der var ingen skelnen mellem nord, syd, øst eller vest. Rummet var åbent. Vores indlærte værdihieraki blev sat til vægs. Hvordan måles og vejes denne kunst? Og er det kunst?

"Nowhere» erobrede det pågældende sted. Det skal forstås helt bogstaveligt. Man kan tale om en belejring af aktiviteter/tableauer, der fyldte udstillingsstedet helt ud, og som beskueren ikke slap for at deltage i, i det øjeblik man overskred dørtærskelen. Udstillingen bestod af 5 udstillingsdele, der var iscenesat af udstillingsarrangører uden for og inden for museet.

Udstillingens forskelligartethed splittede hele tiden forsøget på at få et samlet overblik. Det lod sig ikke gøre. I modsætning til udstillingen "Strange hotel» var det beskueren, der langt mere direkte selv blev aktøren. I "Strange hotel» var vi, os, beskueren lige så meget voyeuren. Den som stod uden for, hvorimod "Nowhere" førte os ind i realiteten, som er her og der og alle vegne. "Nowhere» blev mødestedet for alle mulige synspunkter - vi var alle steder og ingen steder. Titlen på udstillingen fortalte os det allerede. Der blev afgivet og modtaget meddelelser i et væk. Politiske observanser, æstetiske definitioner og økonomiske modeller blev diskuteret og afprøvet.

Udstillingen var ikke scenografiske kulisser, som kunstnerne og deres værker skulle passe ind i. Derimod var udstillingen karakteriseret ved, at kunstnerne og udstillingsarrangørerne havde indgået et partnerskab, der lod kunstnernes aktiviteter kuldkaste institutionens orden.

Museets egen praksis som museum var blevet en del af udstillingen. Bedst som man troede, at nu var udstillingen til ende, blev man forført af et spørgsmåls- 
tegn, som ved sin synlighed skabte irritation og nye spørgsmålstegn. Denne udstillingsdel udstillede museet Louisiana - dets arkitektoniske ramme og samlingens karakteristika. Museet blev således indskrevet i sin egen historiske ramme.

Udstillingen "Nowhere» refererede til den historiske sti af definitioner på kunst. Men i særdeleshed også til hvorledes samtidens egne udtryksformer formidles inden for de institutionelle rammer.

Når vi taler om samtidskunst har vi fåt samlet et ord og et begreb, der i sig selv rummer et modsætningsforhold. "Samtid" refererer til vores øjeblikkelige situation, hvorimod ordet kunst i sig selv rummer en henvisning til et historisk betinget begreb.

Udstillingen "Strange hotel» var nok så meget en iscenesættelse af kunsten, hvor subjektet befandt sig uden for kunsten og som sådan styrede dets retning, hvorimod i udstillingen "Nowhere" blev kunsten sit eget subjekt for iscenesættelsen af os som deltagere i mødet med den.

Udstillingsvirksomheden åbner for muligheden for at scenografere en virkelighed - at synliggøre en problematik i samtidens billeder. Dette behov er allestedsnærværende. Også indenfor de store etablerede institutioner.

\section{SAMSPILLET MELLEM DEN KUNSTNERISKE UDTRYKSFORM OG DE INSTITUTIONELLE RAMMER}

Både den ældre klassiske og den moderne kunst indgår i den gammelkendte iscenesættelse, der karakteriserer en bestemt æstetisk holdning til det enkelte kunstværks placering inden for en udstillingsramme. Men når vi beskæftiger os med samtidskunsten begynder besværlighederne. Samtidskunsten fremtvinger i museet en institutionskritik, som giver det mulighed for at få blotlagt dets egen praksis og ikke kun presentere en facade. Det er her udstillingsaktiviteten får stor betydning. Det er her, at museumsfolk, udstillingsarrangører og kunstnere $i$ et langt tættere arbejdsforhold kan synliggøre, hvorledes et museum består af langt mere komplekse relationer end blot en formidling af oplevelser.

Kunsthistorikerens område er blevet udvidet til også i dag at være organisator for store udstillingsarrangementer. Til gengæld må kunsthistorikeren finde sig i at også andre faggrupper idag blander sig. De flydende grænser inden for kunstens område har også sat sig dybe spor inden for kunstmuseerne.

Bevaringsmæssigt og udstillingsmæssigt er konservatorerne og kunsthistorikerne sat på en alvorlig prøve. De gamle modeller er ikke tilstrækkelige, når museerne erhverver samtidens kunst. Derfor er disse fag også ude for et sandt bombardement fra omverdenen når samtidskunsten gør sin entre på museerne. Kunsthistorikeren skal udover at forske også fungere som en seismograf for sin egen samtid.

Fagets entydighed er blevet sprængt.

\section{LITTERATUR}

Alexis Joachimides (hrsg.): Museumsinszeneierungen: zur Geschichte der Institution des Kunstmuseums, die Berliner Museumslandschaft 1830-1990, Dresden, Verlag der Kunst, 1995.

Christos M. Joachimides und Norman Rosenthal (hrsg.): Metropolis, Stuttgart, Cantz, 1991. 


\section{SUMMARY}

\section{The Museum and the staging of Art}

The staging of art has always been susceptible to changes - according to the needs and purposes of art at different times and in different places.

When we speak of staging art today, we are describing an independent form of expression on a par with other art categories. The breakthrough of staged photography in the 1980s and the appearance of installation art in the 1990s helped to establish this. Staging something has gained a much broader meaning within art.

The artist must resign himself to being one of several parties. Museum staff and curators each contribute with their staging, and artist and art are forced to adapt to the overall idea behind the exhibition. Museum and exhibition activities have also become more closely related. This means that today relations between the artist and the institution are much more direct, and it is not only the institution, but also the artist who is manipulating art.

Museum staff invite artists to manipulate the permanent collections. Thus the artists' task is not limited to producing works which may be acquired by the museum.

In this cooperation the artist lends his authority to the institution. This is based on the realization that the artist's undogmatic views may offer new ways of presenting the museum collections.

But when contemporary art enters the institution, trouble begins. Contemporary art forces the museum to take a critical view of itself as an institution, provoked by the artist's activities. However, these activities may serve to bring out hidden complex relations within the museum.

\section{NOTE}

Denne artikel er en bearbejdet udgave af forelæsning holdt på Louisiana 5. marts 1996 som led i Museumshøjskolens museologiske forelæsninger.
Vibeke Petersen er mag.art. i kunsthistorie ved Kobenhavns Universitet. Overinspektor i maleriog skulpturafdelingen på Statens Museum for Kunst, Kobenhavn.

Adr: Taarbek Strandvej 115,

DK-2930 Klampenborg 